\title{
Body Mass Index and Measures of Body Fat for Defining Obesity and Underweight: A Cross-Sectional Study of Various Specialties in Montenegrin Police Force
}

\author{
Índice de Masa Corporal y Medidas de la Grasa Corporal para Definir la Obesidad y el \\ Bajo Peso: Un Estudio Transversal de Diversas Especialidades en la Policía de Montenegro
}

\author{
Zeljko Spalevic $^{1}$; Veselin Veljovic ${ }^{1}$; Dusko Bjelica ${ }^{2,3}$ \& Bojan Masanovic ${ }^{2,3}$
}

SPALEVIC, Z.; VELJOVIC, V.; BJELICA, D. \& MASANOVIC, B. Body mass index and measures of body fat for defining obesity and underweight: A cross-sectional study of various specialties in Montenegrin police force. Int. J. Morphol., 39(6):1677-1682, 2021.

SUMMARY: The Police force personnel cover an exceptionally wide range of different activities, so it is logical that this heterochronic group has different abilities and characteristics, including daily needs, while changes in body composition and decrease in physical abilities represent a modern issue that has not bypassed this population either. Therefore, the aim of this study is to determine the indicators of the body composition of the Police force personnel, as well as possible differences that might occur in relation to different specialized police units. The subjects of this Cross Sectional study included 115 active-duty male members of the Police force ( $31.54 \pm 10.5$ year-old), divided into four groups, belonging to different specialized units. The sample of variables included five anthropometric measures (body height, body weight, abdominal skinfold, pectoral skinfold and front thigh skinfold) by which two body composition indicators - body mass index (BMI) and body fat percentage (FAT \%) were calculated. The variables were analysed by using the one-way ANOVA and LSD Post Hoc test. It has been determined that there are differences in body composition indicators between the members of different specialized units of the Police force, while overweight was noted among the members of the two subpopulations. This fact indicates that members of certain specialized units of the Montenegrin Police force have adverse nutritional status and the situation may be described as alarming, which may lead to decrease in their physical fitness and effectiveness in service.

KEY WORDS: Anthropometry; Nutrition; Physical fitness; Police force; Montenegro.

\section{INTRODUCTION}

Although the activity of the police officers has evidently changed nowadays because they face different tasks due to increasing rate of a cybercrime relative to street crime (Buckingham et al., 2020), they may, at any point in time, be called to perform demanding tasks, such as pursuing suspects, rescuing civilians, or containment of riots, which will bring their body into a state of great physiological stress (Lockie et al., 2020). In these situations, when a sedentary job is interrupted by extremes of intense physical exertion, potential injury or cardiovascular complications seem far more likely (Dahabreh \& Paulus, 2011; Mittleman \& Mostofsky, 2011). A short previous warm-up would certainly reduce or eliminate the possibility of injury or occurrence of a cardiac ischemia (Foster et al., 1982), but criminals and natural disasters always come unannounced, so this kind of prevention is ruled out. Therefore, both performance-related and healthrelated physical fitness of the police force officers must be on a very high level (Dawes et al., 2016; Kukic' et al., 2020). Musculature must be strong and elastic, with ideal body composition as in top athletes. Why is that so? Just like an athlete who might be just one hundredth of a second away from their victory, a police officer might as well be just one hundredth of a second away from saving someone's life.

Unfavourable body composition or obesity not only represents a ballast and affects efficiency, but also affects health, as an increase in a degree of obesity leads to a greater risk of developing cardiovascular diseases, diabetes, musculo-skeletal disorders, cancer, and also increases possibility of complications, even mortality during various surgical interventions (Rezaeipour, 2020; Popovic et al., 2020a; Rezaeipour et al., 2021). With constant exposure of police officers to a job-related stress: shift work sleep disorder; witnessing or experiencing violent events; remorse

\footnotetext{
${ }^{1}$ Humanistic Studies, University Donja Gorica, Podgorica, Montenegro.

${ }^{2}$ University of Montenegro, Faculty for Sport and Physical Education, Niksic, Montenegro.

${ }^{3}$ Montenegrin Sports Academy, Podgorica, Montenegro.
} 
SPALEVIC, Z.; VELJOVIC, V.; BJELICA, D. \& MASANOVIC, B. Body mass index and measures of body fat for defining obesity and underweight: A cross-sectional study of various specialties in Montenegrin police force. Int. J. Morphol., 39(6):1677-1682, 2021.

for inflicting the injuries and use of force; constant exposure to threat (Violanti \& Aron, 1994; Franke et al., 2002; Chen et al., 2006), it can be said that the police officers are exposed to serious health risks, which is noted in all the above studies.

As a modern way of life (previous four decades) has led to a decrease in the level of physical activity, which further led to decreasing trend in physical activity and changes in body composition among population in general (Masanovic et al., 2020; Popovic et al., 2020b; Johansson et al., 2020), it has logically affected all professions, including the Police force personnel. Accordingly, the results suggest that, in some countries, the percentages of active police officers who are either overweight or obese is higher than among general population (Hartley et al., 2011; Rajaratnam et al., 2011; Zimmerman, 2012). Therefore, they are thought not to be adequately ready to carry out tasks within their professional formations as their capabilities to meet required standards, primarily in terms of strength and endurance, are questioned. Some studies also indicate that police officers die on average much earlier than the general U.S. male population (Arias, 2010), so preventive actions must be taken to solve this problem.

Possible health problems and absence from service place a burden on planned annual budgets in the Ministries of the Interior worldwide. Therefore, over the last decades, numerous studies have been con-ducted examining health status, physical abilities and daily needs of the Police force personnel from the global perspective (Wang et al., 2014; Marins et al., 2019; 2020; Demouet al., 2020). However, given that the police force officers in each country cover an extremely wide range of different activities, it is logical that this population represents a heterochronic group. A specific characteristic of each specialized unit implies their respective different needs, which points to the necessity for conducting further studies to identify differences between the factors that protect or pose a threat to health and physical ability of all subgroups. Their aim would be to fine-tune the programs of physical activities in order to improve general health and physical ability of the personnel in each subpopulation of the police force.

Given the indications that overnutrition and obesity might also be present among the Montenegrin Police force personnel and the absence of any previous study on the nutritional status of various specialized units in the Police force of Montenegro, the aim of this study is to examine body composition, both in general and by subsamples (relative to different specialized units), in order to timely develop prevention programs (if obesity is confirmed), which would prevent a possible decrease in their physical and cognitive abilities that are required for adequate performance of their daily assignments at work.

\section{MATERIAL AND METHOD}

The subjects of this Cross Sectional study included 115 active-duty male members of the Police force that were $31.54 \pm 10.5$ years old (age range 20 - $56 \mathrm{yrs}$ ). The sample was divided into four groups including 34 members of the Special Police Force Unit (33.91 \pm 7.42 yrs), 29 members of the Anti-Terrorist Unit (34.81 \pm 9.3 yrs), 14 members of the Support and Logistics Unit (45.9 $\pm 9.21 \mathrm{yrs)}$ and 38 cadets from the Police Academy (21.64 $\pm 1.65 \mathrm{yrs})$. It is important to note that Montenegro is a small country, and that the measurement covered over $90 \%$ of total personnel within the three above mentioned units (Special Police Force Unit, Anti-Terrorist Unit, Support and Logistics Unit) and 25\% of the Police Academy cadets.

All selected subjects were clinically healthy (there is a protocol of records of systematic medical examinations for the current year in their personal health records), and without any identified physical deformities. All participants were informed of the purpose of the study and any potential risks or benefits of participation before providing voluntary written informed consent prior to participating. The measurement was implemented in the period from 10 February 2021 to 18 February 2021. All procedures were re-viewed and approved by the Ministry of the Interior.

The sample of variables included five anthropometric measures (body height, body weight, abdominal skinfold, pectoral skinfold and front thigh skinfold) that were carried out with the conventional technique according to the ISAC (Marfell-Jones et al., 2012). By these anthropometric measures and in accordance with the Health-Related Physical Fitness Assessment Manual (Kaminsky, 2013), two body composition indicators: body mass index (BMI) and body fat percentage (FAT \%) were calculated. Body mass index was calculated using the following formula: BMI = Body weight $(\mathrm{kg}) /$ Body height $(\mathrm{m} \Sigma)$. Body fat percentage was calculated as follows: FAT $\%=4.95 /$ body density -4.50 ; body density $=1.10938-$ $0.0008267 \mathrm{x}$ (sum of three skinfolds) $+0.0000016 \mathrm{x}$ (sum of three skinfolds) $\sum-0.00002574$ x (age). Selected anthropometric indicators were measured by the qualified assessors, while the quality of their performance was evaluated against the prescribed 'ISAC Manual'. Lastly, the age of each subject was attained directly from their birthdays. The data were analyzed using SPSS 20.0 software (Chicago, IL, USA). Estimations of the variables described in the previous paragraph were calculated descriptively for the whole sample, as well as for each sub-sample. One-Way Analysis of Variance (ANOVA) and LSD Post Hoc test were performed to analyse body composition indicators of the Police force officers, including differences in body mass index and fat percentage 
among the members of different specialized units within the Police. Statistical significance was set at $\mathrm{p}<0.05$.

\section{RESULTS}

Mean values of measured anthropometric measures and obtained body mass indicators of the Montenegrin Police force members are shown in Table I. By taking a look at the average age, it can be noticed that the members of the Support and Logistics Unit (45.9 yrs) are the oldest, while the Police Academy cadets (21.64 yrs.) are the youngest. Members of the Support and Logistics Unit also have the highest values in terms of body height and body weight $(184.94 \mathrm{~cm} ; 99.04$ $\mathrm{kg}$ ), while the lowest average values for both parameters and this indicator were noted among the Police Academy cadets $(181.5 \mathrm{~cm}, 84.82 \mathrm{~kg})$. The highest average values of pectoral and abdominal skinfolds were measured among the members of the Support and Logistics Unit $(23.3 \mathrm{~mm} ; 33.47$ $\mathrm{mm}$ ), while lower average values than in all other groups were measured among the Police Academy cadets (8.12 mm; 19.79 $\mathrm{mm})$. The highest average values of front thigh skinfold were measured among the members of the Special Police Force Unit $(20.68 \mathrm{~mm})$, while members of the Anti-Terrorist Unit have lower average values than all others $(15.58 \mathrm{~mm})$. Body mass index and body fat percentage values are the highest among the members of the Support and Logistics Unit (BMI=28.68; FAT\%=23.74), while the Police Academy cadets have the lowest values thereof $(\mathrm{BMI}=25.73$; FAT $\%=12.63)$.

By reviewing the results, based on the obtained $\mathrm{F}$ values (BMI 11.65 and FAT\% 21.81, p.000) representing the ratio of the factor and residual variance, the existence of differences was confirmed among the subsamples of the examinees in terms of body mass index (BMI) and body fat percentage (FAT \%). Namely, the said F values are larger than value in F Table II, while the significance level is much lower than 0.05 .
Based on the results of the LSD Post Hoc test for body mass index (BMI) shown in Table II, a group that significantly differed in terms of this variable as compared to others was determined. It is the group of the Police Academy cadets (BMI $=25.73$ ) as compared to members of: the Special Police Force Unit (BMI=28.7), the Anti-Terrorist Unit $(\mathrm{BMI}=28.02)$ and the Support and Logistics Unit (BMI=28.88).

Table II. Post Hoc analysis of variance on BMI with study subsamples.

\begin{tabular}{llll}
\hline & SPFU & ATU & L \\
\hline ATU & .267 & & \\
L & .810 & .273 & \\
PA & .000 & .000 & .000 \\
\hline
\end{tabular}

SPFU - Special Police Force Unit; ATU - Anti-Terrorist Unit; LSupport and Logistics Unit; PA - Police Academy cadets

Based on the results of the LSD Post Hoc test for body fat percentage (FAT \%) shown in Table III, the groups that significantly differed in terms of this variable as compared to others were determined. These are: Police Academy cadets (FAT \% $=12.63$ ) as compared to the members of the Support and Logistics Unit (FAT \% $=23.74$ ) and members of the Special Police Force Unit $(\mathrm{FAT}=20.28)$; members of the Anti-Terrorist Unit (FAT \% = 14. 87) as compared to the members of the Support and Logistics Unit $($ FAT $\%=23.74)$ and members of the Special Police Force Unit $(\mathrm{FAT}=20.28)$.

Table III. Post Hoc analysis of variance on FAT\% with study subsamples

\begin{tabular}{llll}
\hline & SPFU & ATU & L \\
\hline ATU & .000 & & \\
L & .420 & .000 & \\
PA & .000 & .920 & .000 \\
\hline
\end{tabular}

SPFU- Special Police Force Unit; ATU-Anti-Terrorist Unit; LSupport and Logistics Unit; PA - Police Academy cadets.

Table I. Anthropometric measures and body composition indicators of study sample and subsamples.

\begin{tabular}{llccrr}
\hline Variables & \multicolumn{1}{c}{ All } & SPFU & ATU & L & PA \\
\cline { 2 - 5 } & & \multicolumn{3}{c}{ Mean \pm SD } & \\
\hline Age & $31.54 \pm 10.5$ & $33.91 \pm 7.42$ & $34.81 \pm 9.3$ & $45.9 \pm 9.21$ & $21.64 \pm 1.65$ \\
Body Height $(\mathrm{cm})$ & $182.5 \pm 6.0$ & $182.08 \pm 5.7$ & $183.01 \pm 5.48$ & $184.94 \pm 9.38$ & $181.5 \pm 4.96$ \\
Body Weight $(\mathrm{kg})$ & $92.01 \pm 11.8$ & $95.35 \pm 11.52$ & $94.12 \pm 10.57$ & $99.04 \pm 14.86$ & $84.82 \pm 7.93$ \\
Pectoral Skinfold $(\mathrm{mm})$ & $12.69 \pm 8.59$ & $16.13 \pm 8.77$ & $9.5 \pm 6.42$ & $23.3 \pm 10.19$ & $8.12 \pm 2.82$ \\
Abdominal Skinfold $(\mathrm{mm})$ & $25.46 \pm 11.21$ & $30.08 \pm 10.97$ & $22.76 \pm 9.23$ & $33.47 \pm 12.3$ & $19.79 \pm 8.56$ \\
Front thigh Skinfold $(\mathrm{mm})$ & $18.07 \pm 7.55$ & $20.68 \pm 7.37$ & $15.58 \pm 4.65$ & $18.59 \pm 7.88$ & $17.43 \pm 8.79$ \\
Body Mass Index $\left(\mathrm{kg} / \mathrm{m}^{2}\right)$ & $27.57 \pm 2.72$ & $28.7 \pm 2.61$ & $28.02 \pm 34$ & $28.88 \pm 3.17$ & $25.73 \pm 1.91$ \\
Body Fat Percentage $(\%)$ & $16.81 \pm 6.62$ & $20.28 \pm 5.71$ & $14.87 \pm 5.10$ & $23.74 \pm 5.61$ & $12.63 \pm 5.01$ \\
\hline
\end{tabular}

SPFU - Special Police Force Unit; ATU - Anti-Terrorist Unit; L - Support and Logistics Unit; PA - Police Academy cadets; Mean - Arithmetic mean; SD - Standard deviation 


\section{DISCUSSION}

This study provides an overview of the existing indicators of body composition of the members of the Police Force of Montenegro, both in terms of the entire population of Montenegrin police officers, and in terms of specifics when it comes to different specialized units. Namely, it included 115 Police force members from various specialized units: Special Police Force Unit, Anti-Terrorist Unit, Support and Logistics Unit, as well as cadets of the Police Academy. The results obtained can be used for several purposes. Primarily for the selection of new recruits in accordance with the general professional requirements for hiring a police officer or a member of any specialized unit. Furthermore, these results can allow a direct comparison of the members of different specialized units in a situation when new recruits must be urgently deployed between different units with different tasks.

Discussing the obtained results, it is worth noting that the body height of the members of the Police Force of Montenegro $(182.5 \mathrm{~cm})$ is among the tallest in the world, which is expected since the Montenegrin general population ranks second behind the Dutch population (Popovic, 2017; 2018). Higher values of average body height were recorded only among Russian police officers $(182.84 \mathrm{~cm})$, while Croatian $(181.57 \mathrm{~cm})$ and American Police officers (180.02 $\mathrm{cm}$ ) were almost as tall as Montenegrin Police officers (Jozic \& Zecic, 2017; Dawes et al., 2019; Heinrich et al., 2020). On the other hand, the height of the Police officers of Brazil $(176 \mathrm{~cm})$, Korea $(174 \mathrm{~cm})$, United Arab Emirates (173.8 $\mathrm{cm})$, Serbia $(172.98 \mathrm{~cm})$ and India $(172.6 \mathrm{~cm})$ is significantly lower (Thayyil et al., 2012; Kukic \& Dopsaj, 2016; Kukic et al., 2018; Kim et al., 2020; Ferraz et al., 2020). However, there is a justified hypothesis that the secular trend in the Montenegrin population is still ongoing, and that the population in the Dinaric Alps (including Montenegrin population) has not yet reached its full genetic potential, because in recent decades it has been under the influence of negative factors (wars, bad economic situation, etc.) (Popovic et al., 2013; Gardasevic et al., 2018; Masanovic et al., 2019). Therefore, it is likely that an average height of male population in Montenegro will increase in the coming years, including members of the Police force of Montenegro.

Researchers were not much focused on body weight; that's why data about this variable are very scarce as compared to body height. However, its ratio to body height is very well documented for the general population, and body fat percentage as well, especially due to the fact that they represent the best indicators of the nutritional status of citizens (including the members of the Montenegrin police), which will be discussed in more detail below.
The results of this study show that differences in BMI and FAT\% are noticed among members of different specialized units of the Police force. Namely, the cadets of the Police Academy have significantly lower values of body mass index (BMI) compared to the members of other specialized units in the Police force, and its values (25.00$29.99 \mathrm{~kg} / \mathrm{m}^{2}$ ) show that the members of each specialized unit in the Police force are on average overweight. However, it should be noted that BMI does not necessarily point to unfavourable nutritional status, because people who have been in training for many years (for example, athletes in some disciplines) will have more muscle mass and higher bone mineral density than a sedentary or nonathletic person, and that adds up to extra pounds. In these cases, the value of the body fat percent-age (FAT \%) should be considered as additional information, and its values, in this case, show that the cadets of the Police Academy and members of the AntiTerrorist Unit are within normal limits. It also shows that cadets of the Police Academy and members of the AntiTerrorist Unit have a significantly lower body fat percentage (FAT \%), as compared to the members of other specialized units in the Police force (Special Police Force Unit and Support and Logistics Unit), where overweight is noted (20 - $25 \%$ ) but not obesity. The reasons for these differences between members of different specialized units of the police, as compared to cadets of the Police Academy, should, primarily, be: a more favourable age structure (20.21 - 24.91 years), as poorer nutritional status is caused by physiological and morphological changes associated with biological aging (Sharp et al., 2008); strict selection criteria regarding physical fitness as a precondition for admission to this educational institution; and finally daily exercises and specific training process that they must master during the educational process. Moreover, the exceptional conditions for exercise provided by the campus of this educational institution, and significantly more free time they can dedicate to their own body as compared to the members of other specialized units should also be noted in this regard. The reasons for better nutritional status when it comes to members of the AntiTerrorist Unit are significantly more rigorous conditions for recruitment in terms of meeting the standards of shape, and professional specialist training that follows general training, which actually leads to a final selection of a policeman who will absolutely meet the requirements of the service. It should also be added that they have designed training processes and specific training on a daily basis, so that their units can always be ready to respond quickly when a crisis situation arises. On the other hand, members of the Special Police Force Unit and Support and Logistics Unit have significantly higher values of treated variables, and the difference is 
particularly evident when it comes to body fat percentage. This can be justified to some extent by the slightly different age structure (31.24 - 56.99 years) of the members of the Support and Logistics Unit, and also by the fact that they mostly work on highly sophisticated technology devices, and thus the scope of their physical activity is reduced and the possibility of spending more time doing physical activity is reduced to a minimum. On the other hand, when it comes to members of the Special Police Force Unit, there is no justification for their currently unfavourable nutritional status (on average overweight, and as many as $20 \%$ of members of this Unit are within the obese group), and it can be said that the situation is alarming, which may lead to a decrease in their physical fitness and effectiveness in service.

This study is limited due to the fact that the measurement has been carried out during the ongoing COVID-19 pandemic, when the entire world population is to a certain degree limited in terms of mobility, so it is likely that, under regular circumstances, the results would be different. Moreover, about $70 \%$ of the members of the Special Police Force Unit, Anti-Terrorism Unit and Support and Logistics Units in the previous six months have been positive for coronavirus, which means that they have been isolated for a certain period of time, without any vigorous physical activity as advised by MD. On the other hand, the main strength of this study is a quality and large sample (90\% of the total personnel: Special Police Force Unit, AntiTerrorist Unit, Support and Logistics Unit; $25 \%$ of cadets of the Police Academy), which resulted in creating model characteristics of the Montenegrin Police Force officers when it comes to body composition indicators, including characteristics of each specialized unit of the Police force. However, given the heterogeneous composition of the members of the Police Force of Montenegro, the recommendation for future research is based on the idea that regular systematic measurements should include the entire personnel of the Montenegrin police. The nutritional status of the Montenegrin police force personnel could thus be constantly monitored, and based on the measurement results, the physical training and nutrition program of the entire Montenegrin police personnel could be adjusted. This would be aimed at adopting adequate and specific policies that should lead to improved capability of the Montenegro Police force personnel, and the best possible level of protection of public order in Montenegro. Moreover, it should be added that this is one in a series of studies that emphasize the need to reexamine the reliability of the BMI table values for diagnosing a level of nutrition of the population living in the Dinaric Alps, because the specific characteristics of the matter require establishing of special standards for this region for further studies (Starc et al., 2019; Banjevic et al., 2020).
SPALEVIC, Z.; VELJOVIC, V.; BJELICA, D. \& MASANOVIC, B. Índice de masa corporal y medidas de la grasa corporal para definir la obesidad y el bajo peso: Un estudio transversal de diversas especialidades en la policía de Montenegro. Int. J. Morphol., 39(6):1677-1682, 2021.

RESUMEN: El personal de la fuerza policial cubre una amplia gama de actividades diferentes, por lo que es lógico que este grupo heterocrónico tenga diferentes habilidades y características, incluyendo las necesidades diarias, mientras que los cambios en la composición corporal y la disminución de las capacidades físicas representan un tema de actualidad que también es evidente en esta población. Por tanto, el objetivo de este estudio fue determinar los indicadores de la composición corporal del personal policial, así como las posibles diferencias que pudieran presentarse en relación a las distintas unidades policiales especializadas. Los sujetos de este estudio transversal incluyeron a 115 hombres en servicio activo de la policía (31,54 \pm 10,5 años), divididos en cuatro grupos, pertenecientes a diferentes unidades especializadas. La muestra de variables incluyó cinco medidas antropométricas (altura corporal, peso corporal, pliegue cutáneo abdominal, pliegue cutáneo pectoral y pliegue cutáneo frontal del muslo) mediante las cuales se calcularon dos indicadores de composición corporal: índice de masa corporal (IMC) y porcentaje de grasa corporal (\% FAT). Las variables se analizaron mediante ANOVA de una vía y la prueba LSD Post Hoc. Se determinó que existen diferencias en los indicadores de composición corporal entre los integrantes de las distintas unidades especializadas de la Policía, mientras que se observó sobrepeso entre los integrantes de las dos subpoblaciones. Este hecho indica que los miembros de determinadas unidades especializadas de la Policía de Montenegro tienen un estado nutricional adverso y la situación puede calificarse de alarmante, lo que puede llevar a una disminución de su aptitud física y eficacia en el servicio.

PALABRAS CLAVE: Antropometría; Nutrición; Aptitud física; Fuerza policial; Montenegro.

\section{REFERENCES}

Arias, E. United States life tables, 2006. Hyattsville, MD, National Center for Health Statistics, 2010.

Banjevic, B.; Popovic, S. \& Masanovic, B. Body mass index and body fat percentage of armed forces personnel in montenegro among different age groups. Iran J. Public. Health., 49(5):1010-11, 2020.

Buckingham, S. A.; Morrissey, K.; Williams, A. J.; Price, L. \& Harrison, J. The Physical activity wearables in the police force (PAW-Force) study: acceptability and impact. BMC public health, 20(1):1-16, 2020.

Chen, H.; Chou, F. H.; Chen, M.; Su, S. F.; Wang, S. Y.; Feng, W. W.; Chen, P. C.; Lai, J. Y; Chao, S. S; Yang S. L; Tsai, T. C.; Tsai, K. Y; Lin, K. S.; Lee, C. Y. \& Wu, H. C. A survey of quality of life and depression for police officers in Kaohsiung, Taiwan. Qual. Life Res., 15(5):925-32, 2006.

Dahabreh, I. J. \& Paulus, J. K. Association of episodic physical and sexual activity with triggering of acute cardiac events: systematic review and meta-analysis. JAMA, 305:1225-33, 2011.

Dawes, J. J.; Orr, R. M.; Siekaniec, C. L.; Vanderwoude, A. A. \& Pope, R. Associations between anthropometric characteristics and physical performance in male law enforcement officers: A retrospective cohort study. Ann. Occup. Environ. Med., 28(1):1-7, 2016. 
Dawes, J. J.; Lockie, R. G.; Kornhauser, C. L.; Holmes, R. J. \& Orr, R. M. Relationships between absolute and relative strength and power in male police officers of varying strength levels. J. Sci. Sport and Exercise, 1(3):281-8, 2019.

Demou, E.; Hale, H. \& Hunt, K. Understanding the mental health and wellbeing needs of police officers and staff in Scotland. Police Pract. Res., 21(6):70216, 2020.

Ferraz, A. D. F.; Andrade, E. L. D.; Viana, M. V.; Rica, R. L.; Bocalini, D. S. \& Figueira, A. Physical activity level and sedentary behavior of military police staff. Rev. Bras. de Medicina do Esporte, 26(2):117-21, 2020.

Foster, C.; Dymond, D. S.; Carpenter, J. \& Schmidt, D. H. Effect of warmup on left ventricular response to sudden strenuous exercise. J. Appl. Physiol. Respir. Environ. Exerc. Physiol., 53(2):380-3, 1982.

Franke, W. D.; Ramey, S. L. \& Shelley, M. C. 2nd. Relationship between cardiovascular disease morbidity, risk factors, and stress in a law enforcement cohort. J. Occup. Environ. Med., 44(12):1182-9, 2002.

Gardasevic, J.; Masanovic, B. \& Arifi, F. Relationship between tibia length measurements and standing height: A prospective regional study among adolescents in northern region of Kosovo. Sport Mont, 16(3):51-5, 2018.

Hartley, T. A.; Burchfiel, C. M.; Fekedulegn, D.; Andrew, M. E. \& Violanti, J. M. Health disparities in police officers: comparisons to the US general population. Int. J. Emerg. Ment. Health, 13(4):211-20, 2011.

Heinrich, K. M.; Gurevich, K. G.; Arkhangelskaia, A. N.; Karazhelyaskov, O. P. \& Poston, W. S. Despite low obesity rates, body mass index underestimated obesity among Russian police officers when compared to body fat percentage. Int. J. Environ. Res. Publi.c Health, 17(6):1937, 2020.

Johansson, L.; Brissman, M.; Morinder, G.; Westerståhl, M. \& Marcus, C. Reference values and secular trends for cardiorespiratory fitness in children and adolescents with obesity. Acta Paediatr., 109(8):1665-71, 2020.

Jozic, M. \& Zecic, M. Differences in morphological characteristics between members of intervention and special police. In 8th International Scientific Conference on Kinesiology: 20th anniversary (608-611), Opatia, Croatia, The Faculty of Kinesiology, 2017.

Kaminsky, A. Prirucnik za procenu fizicke forme povezane sa zdravljem. Beograd, Data Status, 2013.

Kim, J.; So, W. Y. \& Kim, S. Association between body fat percentage and physical performance in male korean police officers. Sustainability, 12(9):3868, 2020.

Kukic, F. \& Dopsaj, M. Structural analysis of body composition status in Abu Dhabi police personnel. NBP - J. Crim. Law, 21(3):19-38, 2016.

Kukic, F.; Dopsaj, M.; Dawes, J.; Orr, R. \& Cvorovic, A. Use of human body morphology as an indication of physical fitness: implications for police officers. Int. J. Morphol., 36(4):1407-12, 2018.

Kukic, F.; Heinrich, K. M.; Koropanovski, N.; Poston, W. S.; Cvorovic', A.; Dawes, J. J.; Orr, R. \& Dopsaj, M. Differences in body composition across police occupations and moderation effects of leisure time physical activity. Int. J. Environ. Res. Public. Health, 17(18):6825, 2020.

Lockie, R. G.; Ruvalcaba, T. R.; Stierli, M.; Dulla, J. M.; Dawes, J. J.; \& Orr, R. M. Waist circumference and waist-to-hip ratio in law enforcement agency recruits: Relationship to performance in physical fitness tests. $J$. Strength Cond. Res., 34(6):1666-75, 2020.

Marfell-Jones, M. J.; Stewart, A. D. \& de Ridder, J. H. International standards for anthropometric assessment. Wellington, New Zealand, International Society for the Advancement of Kinanthropometry, 2012.

Marins, E. F.; David, G. B. \& Del Vecchio, F. B. Characterization of the physical fitness of police officers: a systematic review. J. Strength Cond. Res., 33(10):2860-74, 2019.

Marins, E. F.; Cabistany, L.; Farias, C.; Dawes, J. \& Del Vecchio, F. B. Effects of personal protective equipment on metabolism and performance during an occupational physical ability test for Federal Highway Police Officers. J. Strength Cond. Res., 34(4):1093-102, 2020.

Masanovic, B.; Bavcevic, T. \& Prskalo, I. Regional differences in adult body height in Kosovo. Monten. J. Sports Sci. Med., 8(1):69-76, 2019.

Masanovic, B.; Gardasevic, J.; Marques, A.; Peralta, M.; Demetriou, Y.; Sturm, D. J. \& Popovic, S. Trends in physical fitness among school-aged children and adolescents: A systematic review. Front. Pediatr., 8:627529, 2020.
Mittleman, M. A. \& Mostofsky, E. Physical, psychological and chemical triggers of acute cardiovascular events: preventive strategies. Circulation, 124(3):346-54, 2011.

Popovic, S.; Banjevic, B.; Masanovic, B. \& Bjelica, D. Body mass index and measures of body fat for defining obesity and underweight: A crosssectional of various specialties in montenegrin army soldiers. Iran. J. Public. Health, 49(12):2376-83, 2020a.

Popovic, S.; Bjelica, D.; Molnar, S.; Jaksic, D. \& Akpinar, S. Body height and its estimation utilizing arm span measurements in serbian adults. Int. $J$. Morphol., 31(1):271-9, 2013.

Popovic, S. Local geographical differences in adult body height in Montenegro. Monten. J. Sports Sci. Med., 6(1):81-7, 2017.

Popovic, S. Arm-span measurement as an alternative estimation of true height in Montenegrin young adults of both sexes: A national survey. Anthropol. Noteb., 24(1):53-67, 2018.

Popovic, S.; Masanovic. B.; Martinovic, S.; Bjelica, D. \& Gardasevic, J. Trajectories in body height, body weight, BMI, and nutrition status from 1979 to 1987: A measurement-based analysis of 15,717 male adolescents from the capital city of Montenegro. Front. Public. Health, 8:610358, 2020 b.

Rajaratnam, S. M.; Barger, L. K.; Lockley, S. W.; Shea, S. A.; Wang, W.; Landrigan, C. P.; O'Brien, C. S.; Qadri, S.; Sullivan, J. P.; Cade, B. E.; Epstein, L. J.; White, D. P.; Czeisler, C. A. \& Harvard Work Hours, Health and Safety Group. Sleep disorders, health, and safety in police officers. JAMA, 306(23):2567-78, 2011.

Rezaeipour, M. Investigation of pool workouts on weight, body composition, resting energy expenditure, and quality of life among sedentary obese older women. Monten. J. Sports Sci. Med., 9(1):67-72, 2020.

Rezaeipour, M.; Apanasenko, G. L. \& Raghi, Z. Efficacy of the WATERinMOTION Aquatics Exercise Programme on the Body Weight and Composition of Sedentary Older Women with Overweight/Obesity. Monten. J. Sports Sci. Med., 10 (2):19-24. 2021.

Sharp, M.; Knapik, J. \& Wallker, L. Physical fitness and body composition after a 9-month deployment to Afghanistan. Med. Sci. Sports Exerc., 40(9):1687-92, 2008.

Starc, G.; Popovic, S.; Dordic, V.; Ostojic, S.; Music Milanovic, S.; Kujundzic, E.; Spiroski, I.; Duric, S.; Masanovic, B.; Sember, V. \& Leskosek, B. Differences in body height between the contemporary Western Balkan children and the WHO growth references core sample. Anthropol. Noteb., 25(3):55-67, 2019.

Thayyil, J.; Jayakrishnan, T. T.; Raja, M. \& Cherumanalil, J. M. Metabolic syndrome and other cardiovascular risk factors among police officers. $N$. Am. J. Med. Sci., 4(12):630-5, 2012.

Violanti, J. M. \& Aron, F. Ranking police stressors. Psychol. Rep., 75(2):8246, 1994.

Wang, Y.; Zheng, L.; Hu, T. \& Zheng, Q. Stress, burnout, and job satisfaction: Case of police force in China. Public. Pers. Manage., 43(3):325-39, 2014.

Zimmerman, F. H. Cardiovascular disease and risk factors in law enforcement personnel: a comprehensive review. Cardiol. Rev., 20(4):159-66, 2012.

\section{Corresponding author: \\ PhD Bojan Masanovic \\ Faculty for Sport and Physical Education \\ University of Montenegro \\ Narodneomladine bb \\ 81400 Niksic \\ MONTENEGRO}

E-mail: bojanma@ucg.ac.me

Received: 05-07-2021

Accepted: 26-08-2021 